\title{
PKM Pelatihan dan Pembelajaran Tata Cara Membaca Al-Qur'an dengan Ilmu Tajwid dengan Media Mobile di TPQ AT-Tarbiyah
}

Ahmad Khairi ${ }^{1}$, Abdur Rohman Wahid ${ }^{2}$, Ach Romli ${ }^{3}$, Achmad Sholihin ${ }^{4}$, Afan maulana Ishaq ${ }^{5}$

Fakultas Teknik Jurusan Informatika Universitas Nurul Jadid 1,2,3,4,5

\{khairi9@unuja.ac.id ${ }^{1}$,rxhxxn27@gmail.com², Ixiaojie105@gmail.com³, mr.sholihin620@gmail.com ${ }^{4}$, afanmaulana252@gmail.com $\left.{ }^{5}\right\}$

\begin{tabular}{ll}
\hline \multicolumn{1}{c}{ Submission: 01/09/2021 Received: 31/12/2021 Published: 31/12/2021 } \\
\hline Keywords: & Abstract. Community service carried out at TPQ AT-Tarbiyah is a \\
Tajwid, & learning model carried out using mobile media or or Android. Tajweed \\
$T P Q$, & is a science that studies or explains how to read the Qur'an properly \\
Android & and correctly. Allah SWT has ordered to read the Qur'an with tartil, \\
& which is to improve the readings of the letters of the Qur'an in a clear, \\
& orderly and unhurried manner and recognize places that are in \\
& accordance with the laws of recitation. The science of recitation aims \\
& to provide guidance on how to pronounce the correct verse so that the \\
& pronunciation and meaning are preserved. But in reality there are still \\
& many people who do not understand about reading the Qur'an \\
& properly and correctly for various reasons. One of the reasons for not \\
& understanding the laws of recitation. In this service, it produces \\
& learning media to read the Qur'an with Tajweed Science for Android- \\
Based Beginners and provide assistance to the use of applications that \\
have been built.
\end{tabular}

Katakunci:

Tajwid,

TPQ

Android,

\begin{abstract}
Abstrak. Pengabdian kepada masyarakat yang di laksanakan di TPQ AT-Tarbiyah merupakan model pembelajaran yang di lakukan dengan menggunakan media mobile atau atau android. Dimana Ilmu tajwid merupakan ilmu yang mempelajari atau menerangkan tata cara membaca al-Qur'an dengan baik dan benar. Allah SWT telah memerintahkan membaca al-Qur'an dengan tartil yaitu membaguskan bacaan huruf-huruf Al-Qur'an dengan terang, teratur dan tidak terburu-buru serta mengenal tempat-tempat sesuai dengan hukum-hukum tajwid. IImu tajwid bertujuan untuk memberikan tuntunan bagaimana pengucapan ayat yang tepat sehingga lafal dan maknanaya terpelihara. Namun pada kenyataannya masih banyak orang yang belum memahami tentang membaca Al-Qur'an yang baik dan benar dengan berbagai alasan. Salah satunya beralasan tidak memahami hukum-hukum tajwid. Pada pengabdian ini menghasilkan media Pembelajaran Membaca Al-Qur'an Dengan IImu Tajwid Bagi Pemula Berbasis Android serta melakukan pendampingan terhadap penggunaan aplikasi yang telah dibangun.
\end{abstract}




\section{Pendahuluan}

Membaca Al-Qur'an dengan perlahan atau tidak tergesa-gesa dengan menggunakan IImu Tajwid adalah kewajiban bagi setiap muslim. Artinya setiap muslim harus mempelajari tata cara membaca Al-Qur'an dengan benar sesuai dengan IImu Tajwid. Sebagaimana firman Allah swt. QS. AlMuzzammil/73:4.

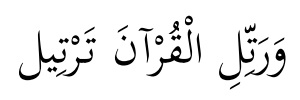

Terjemahnya:

"Dan Bacalah Al Quran itu dengan tartil (perlahan-lahan)". (Agama, 2002)

Dalil tersebut dengan menyatakan bahwa dalam membaca Al-Qur'an haruslah secara perlahan dan tidak tergesa-gesa dimana harus memperhatikan tata cara membacanya sesuai dengan IImu Tajwid. IImu Tajwid adalah mengeluarkan setiap huruf dari makhrajnya dan memberikan hak setiap huruf yaitu sifat yang melekat pada huruf tersebut seperti qolqolah, hams, dll. Serta mustahaq huruf yang artinya sifat yang melekat pada huruf yang terjadi karena sebab-sebab tertentu, seperti idzhar, idgham, dll. Manfaat Ilmu Tajwid sendiri ialah menjaga lidah dari kesalahan saat membaca Al-Qur'an (Katsir, 2014).

KH. As'ad Humam dalam bukunya dijelaskan "Cara Cepat Belajar Tajwid Praktis" (kelanjutan dari 6 jilid buku iqra) menegaskan bahwa hukum mempelajari Ilmu Tajwid (mengetahui istilah-istilah dan hukum-hukumnya) adalah Fardhu Kifayah sedangkan membaca Al-Qur'an dengan benar (menbaguskan bacaan huruf Al-Qur'an dengan terang, teratur dan tidak terburu-buru serta mengenal temapt waqof sesuai dengan aturan IImu Tajwid) adalah Fardhu Ain (wajib bagi tiap kaum). Sedangkan Imam Ali bin Tholib mengatakan bahwa Tajwid adalah mengeluarkan setiap huruf dari makhrajnya dan memberikan hak setiap huruf (yaitu sifat yang melekat pada huruf tersebut seperti qolqolah, hams, dll) dan mustahaq huruf (yaitu sifat-sifat huruf yang terjadi karena sebab-sebab tertentu, seperti idzhar, idgham (Humam, 2002). 
Ilmu Tajwid merupakan konsep ilmu yang menjelaskan tentang tata cara membaca AL-Qur'an, baik membunyikan huruf, tempat yang tepat untuk berhenti, sebab-sebab hukum-hukum bacaan, dan hal lainnya yang terkait dengan bacaan AL-Qur'an. Sedangkan IImu Tajwid ini merupakan suatu kewajian (Fardhu Kifayah). Artinya mempelajari ilmu tajwid secara mendalam dan tidak diharuskan bagi setiap orang, tetapi cukup diwakili oleh beberapa orang saja. Namun, jika dalam satu kaum tersebut tidak ada seorangpun yang mempelajari IImu Tajwid, maka berdosalah kaum itu. Sedangkan hukum memabaca Al-Qur'an dengan memakai aturan-aturan tajwid adalah fardu ain atau kewajiban pribadi. Membaca al-Qur'an sebagai sebuah ibadah haruslah dilaksanakan sesuai ketentuan-ketentuan itulah yang terangkum dalam Ilmu Tajwid (Abdurrohim, 2003).

Android adalah sistem operasi yang berbasis Linux untuk telepon seluler seperti smartphone dan komputer tablet. Android menyediakan platform terbuka bagi para pengembang untuk menciptakan aplikasi mereka sendiri untuk digunakan oleh bermacam peranti bergerak (Enterprise, 2010). Dalam pembelajaran membaca Al-Qur'an dengan ilmu tajwid maka dibuatlah aplikasi android untuk menumbuhkan minat siswa dalam mempelajari ilmu tajwid dengan media yang menarik. Hal ini dapat membuat siswa mudah dalam memahami bagaimana cara menentukan hukum bacaan dan membaca al-qur'an dengan lancar dan benar tanpa harus didampingi oleh guru. Hasil dari aplikasi ini bisa dijalankan pada smartphone, sehingga membuat siswa mudah dan tidak bosan dalam mempelajari ilmu tajwid melalui canggihnya media pembelajaran berbasis android. Aplikasi ini bisa dipakai oleh khalayak umum karena bisa diinstall dan diaplikasikan pada smartphone._Hal tersebut menunjukkan membaca alqur'an dengan ilmu tajwid tidak ketinggalan terhadap perkembangan teknologi, karena bisa melaju beriringan dengan arus teknologi.

IImu tajwid tidak hanya popular dikalangan santri yang terdapat di pondok pesantren saja. Saat ini ilmu tajwid juga dipelajari pada Taman Pendidikan Al-Qur'an (TPQ) untuk anak-anak yang terdapat di masyarakat seperti halnya TPQ At-Tarbiyah yang terdapat di perumahan De Tanjung Raya (DeTar). TPQ At-Tarbiyah didirikan oleh ketua takmir masjid Detarbiyah beserta pengurus paguyuban perumahan DeTar. TPQ tersebut didirikan disebabkan karena kurangnya pembelajaran IImu Tajwid di sekolah-sekolah formal maupun dikalangan masyarakat DeTar. Berdasarkan hasil wawancara 
yang telah dilakukan pada TPQ At-Tarbiyah, metode yang digunakan dalam proses pembelajaran ilmu tajwid menggunakan pendekatan ceramah serta menghafal hukum-hukum bacaan dalam ilmu tajwid.

Media pembelajaran IImu Tajwid yang digunakan oleh ustadzah dan murid yang terdapat di TPQ At-Tarbiyah masih menggunakan media konvensional yaitu buku ataupun tulisan guru di papan. Hal tersebut terkesan monoton dan tidak menarik sehingga membuat siswa bosan untuk belajar Ilmu Tajwid.

Terdapat beberapa penyebab murid sulit untuk mempelajari ilmu tajwid diantaranya yakni murid kurang memiliki ketertarikan dalam memperlajari ilmu tajwid karena setelah pulang sekolah rata-rata murid sering bermain smartphone. Untuk mempermudah murid dalam mempelajari IImu Tajwid serta agar memmiliki ketertarikan dalam belajar ilmu tajwid dibutuhkan pengembangan media pembelajaran ilmu tajwid berbasis mobile yang dapat diakses dengan mudah pada smartphone. Oleh sebab itu, fokus dalam pengabdian ini yakni membuat media pembelajaran ilmu tajwid serta memberikan pelatihan penggunakan media yang telah dirancang yang diharapkan mampu memberikan dampak yang lebih baik bagi murid dalam mempelajari ilmu tajwid. Sistem yang dibangun berbasi android. Android dipilih karena mayoritas masyarakat perumahan DeTar menggunakan Smartphone Android.

\section{Metode}

Metode yang digunakan dalam pengadian pelatihan dan pembelajaran tata cara membaca Al - Qur'an menggunakan beberapa tahap-tahapan hingga sampai implemantasi aplikasi ke lapangan. Tahapan rinciannya tertera dalam bagan atau alur diagram seperi gambar berikut: 


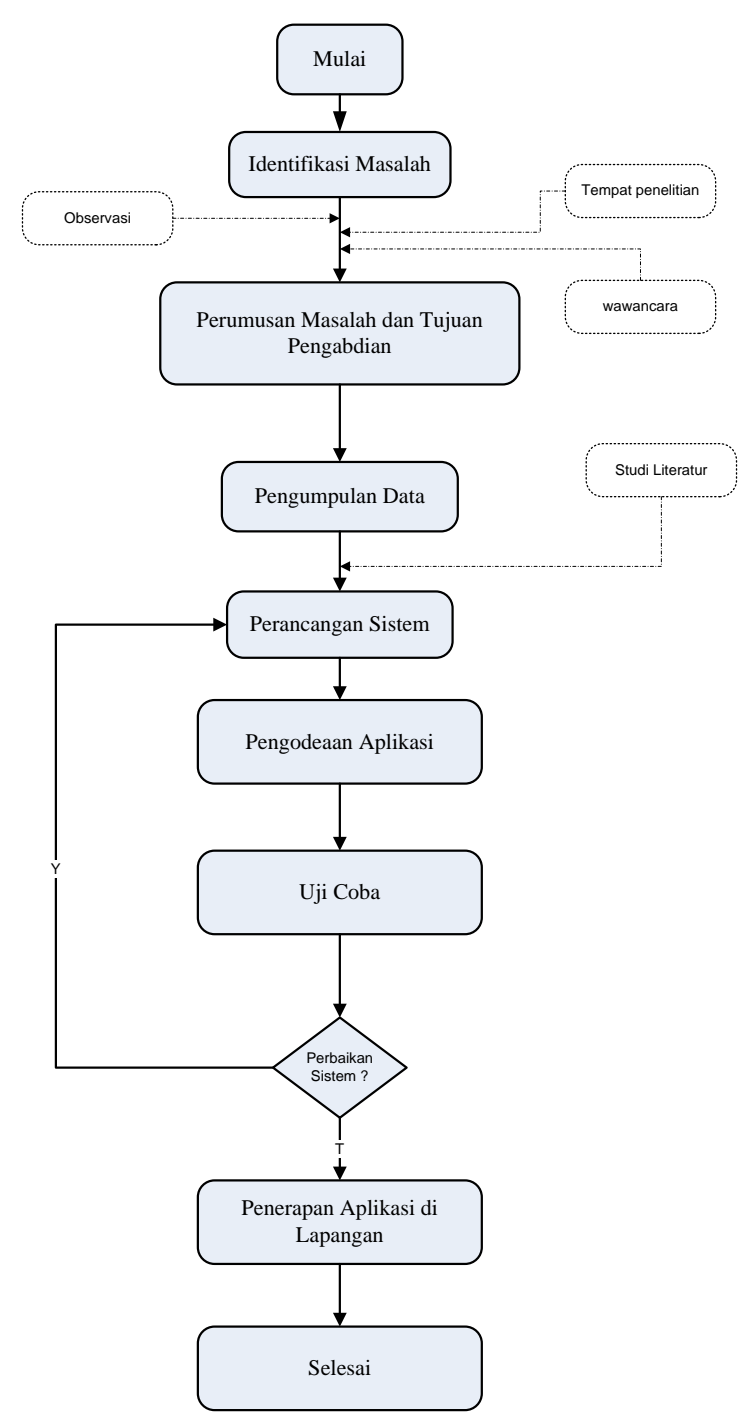

Gambar 1. Bagan Metode Pengabdian

Detail rincian urutan metode di atas dipaparkan sebaga berikut:

\section{Identifikasi Masalah}

Mengindentifikasi masalah dengan cara melakukan observasi dan wawancara di tempat penelitian. Wawancara dilakukan kepada ustazahustazah di TPQ AT- Tarbiyah. Dan melakukan observasi langsung kepada anak-anak di TPQ AT-Tarbiyah. 


\section{Perumusan Masalah dan Tujuan Pengabdian}

Perumusan masalah dan tujuan pengadian ditentukan setelah tahapan identifikasi masalah selesai terlaksana. Permasalah yang ada pada tempat pengabdian tersebut diselesaikan dengan menggunakan teknologi yang terkini dan menjadi tujuan dari pengabdian. Karena pengabdian ini bertujuan untuk memberikan kemudahan kepada anak-anak dalam membaca alqur'an dan mempeljari ilmu tajwid

\section{Perancangan Sistem}

Tahapan perancangan sistem menyesuaikan dengan sistem manual yang ada dan dibuat menjadi mudah dan sederhana tentunya dalam sistem komputerisasi. Perancangan sistem meliputi: Flowchart manual dan terkomputerisasi, DFD (Data Flow Diagram) dan ERD (Entitas Relasi Database). Ketiga perancangan sistem tersebut teralisasi dalam runtutan kegiatan penelitian sebelumnya.

\section{Pengodeaan Aplikasi}

Pengodeaan Aplikasi menggunakan Berbasis Android (Eclipse). Desain interface menggunakan Css dan Framework Bootstrap, sehingga tampilan menjadi responsif. Desain web responsif telah menerima perhatian populer dalam beberapa tahun terakhir karena mereka dapat memenuhi berbagai resolusi terminal internet (Jiang et al., 2014), maka dari itu, desain website pada zaman globalisasi saat ini penerapan web responsif seperti menjadi wajib karena penggunaa HP atau mobile lebih banyak dari pada Komputer(Raharjo, 2013)

\section{Uji Coba}

Uji coba ini sudah dilakukan pada proses penelitian sebelumnya. Akan tetapi tetap dilakukan uji coba sebelum melakukan pengabdian kepada masyarakat, hal itu uji coba tersebut hanya untuk memastikan bahwa aplikasi siap untuk digunakan. Dalam tahapan uji coba jika terdapat error atau kode yang tidak bisa maka akan tetap dilakukan perbaikan sistem dan tahapan ini akan dilakukana sampai siap untuk penerapan di lapangan. 


\section{Penerapan Aplikasi di Lapangan}

Tahapan ini merupakan implmentasi akhir pada pelatihan dan pembelajaran tata cara membaca al-quran dan ilmu tajwid berbasis android. Pendampingan penggunaan aplikasi dilakukan terhadap beberapa ustazah dan murid di TPQ At-tarbiyah.

\section{Hasil dan Pembahasan}

\section{Implementasi Program}

\section{Tampilan Awal}

Pada tampilan awal, user akan dihadapkan dengan satu tombol yaitu tombol mulai (tombol masuk) untuk memulai media pembelajaran dari aplikasi. seperti pada gambar 3.1 :

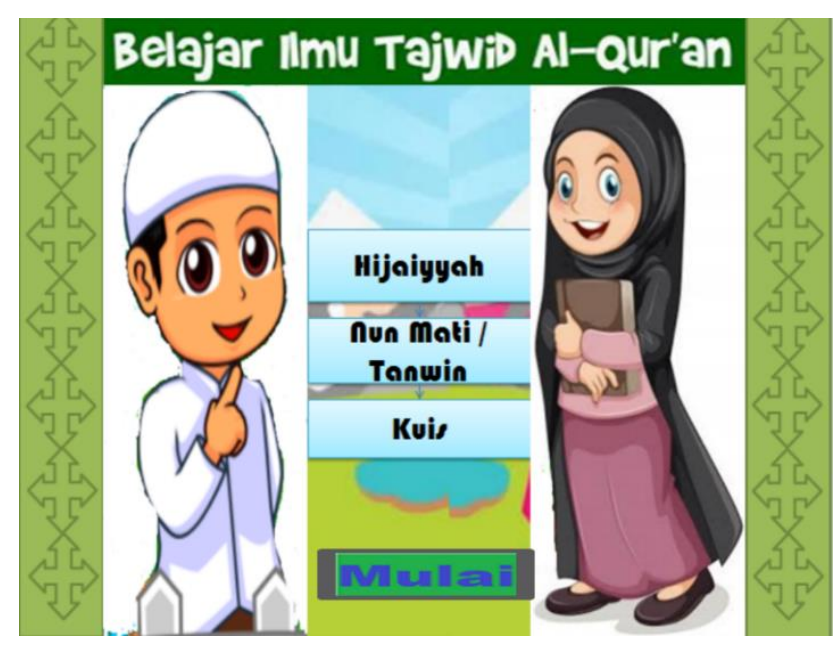

Gambar 3. 1. Tampilan Awal

\section{Tampilan Menu Utama}

Pada halaman menu utama akan menampilkan beberapa menu yang bisa dipilih oleh user yaitu profil, materi, bantuan, keluar. adapun tampilan menu utama ialah seperti pada gambar 3.2 : 


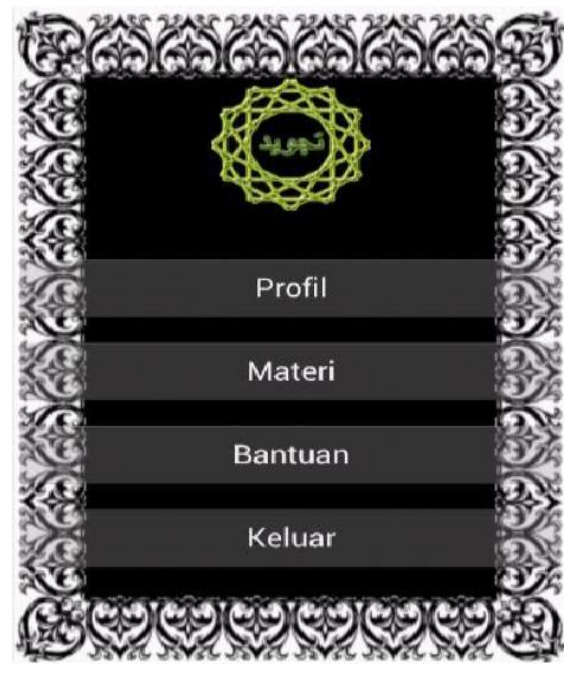

Gambar 3.2. Tampilan Menu Utama

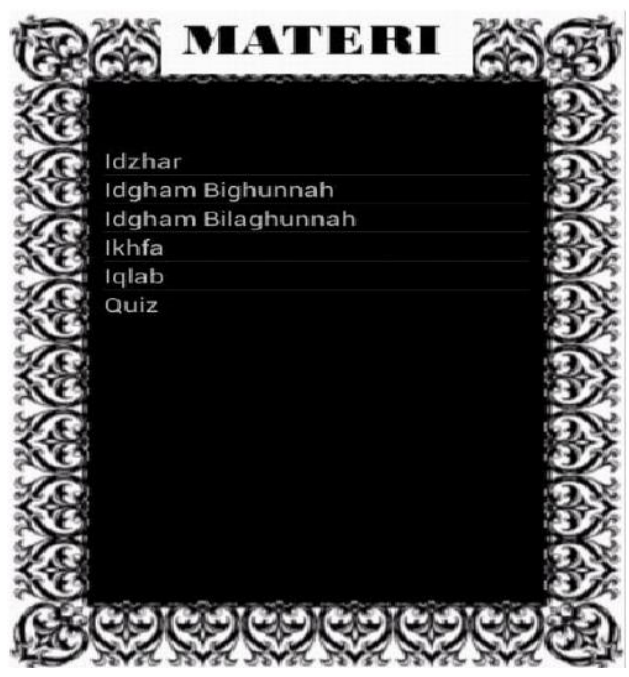

Gambar 3.3 menu utama

\section{Tampilan Menu Materi}

Pada menu materi akan menampilkan beberapa materi yang terdiri dari lima hukum bacaan ilmu tajwid dan satu kuis. dimana hukum bacaan ini tersiri dari beberapa macam materi yaitu idzhar, idgham bighunnah, idgham bilaghunnah, iqlab dan ikhfa'. sedangkan kuis ini terdiri dari 10 soal kuis yang diambil dari lima hukum bacaan tersebut. seperti pada gamba 3.3.

\section{Tampilan Nun Mati}

Pada halaman nun mati ada beberapa materi hukum bacaan yaitu terdiri dari lima materi dan satu kuis, diantaranya yaitu huruf idzhar, idgham bighunnah, idgham bilaghunnah, ikhfa, dan iqlab. Sedangkan kuis ini terdiri dari 10 soal yang di ambil dari lima hukum bacaan tersebut. Seperti pada gambar 3.4 : 


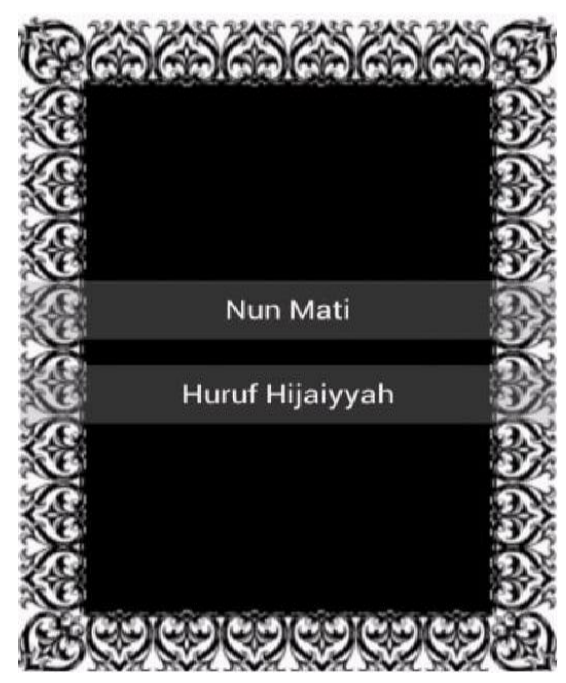

Gambar 3.4 menu materi nun mati

\section{Idzhar}

Idzhar menurut bahasa berarti jelas atau terang sedangkan menurut istilah yaitu apabila nun mati atau tanwin bertemu dengan salah satu huruf yang 6 maka harus dibaca jelas atau terang. Adapun huruf idzhar seperti pada gambar 3.5.

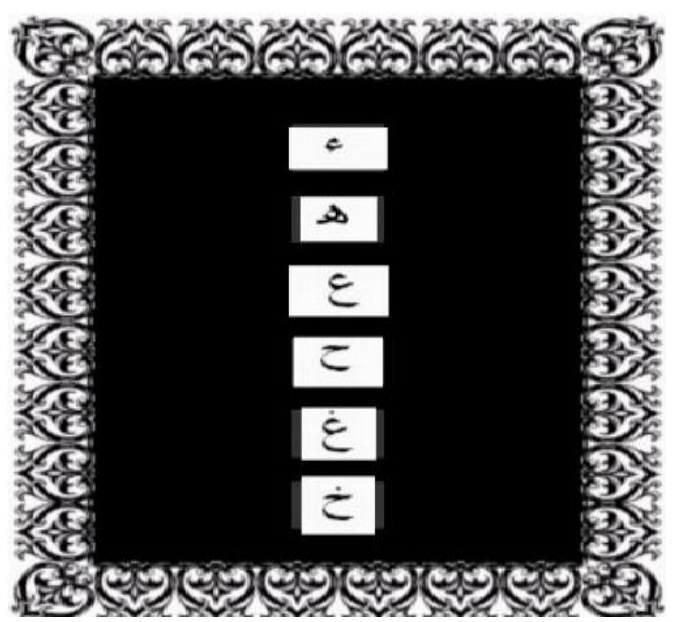

Gambar 3.5 Huruf idzhar

\section{Idgham Bigunnah}

Idgham bighunnah menggabungkan bunyi nun sukun atau tanwin ke huruf idgham dengan didegungkan. Adapun huru idgham bighunnah seperti pada gambar 3.6 


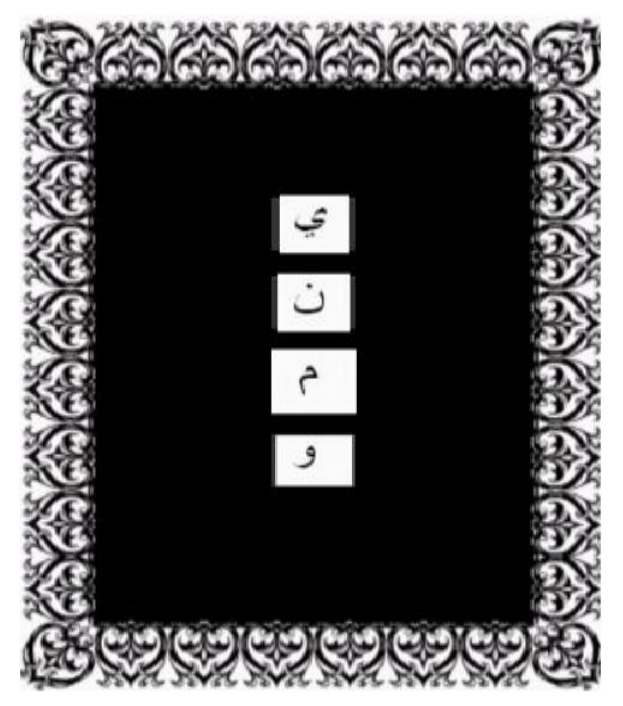

Gambar 3.6 Huruf idgham bighunnah

\section{Idgham bilaghunnah}

Idgham bilahunnah secara bahasa berarti tanpa dengung, sedangkan menurut istilah ialah hukum bacaan yang dibaca tapa mendengung. Adapun huruf idgham bilaghunnah seperti pada gambar 3.7

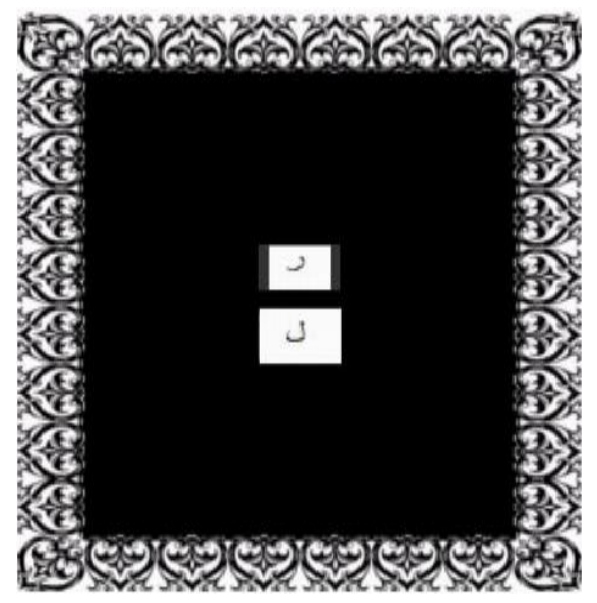

Gambar 3.7 idgham bilaghunnah

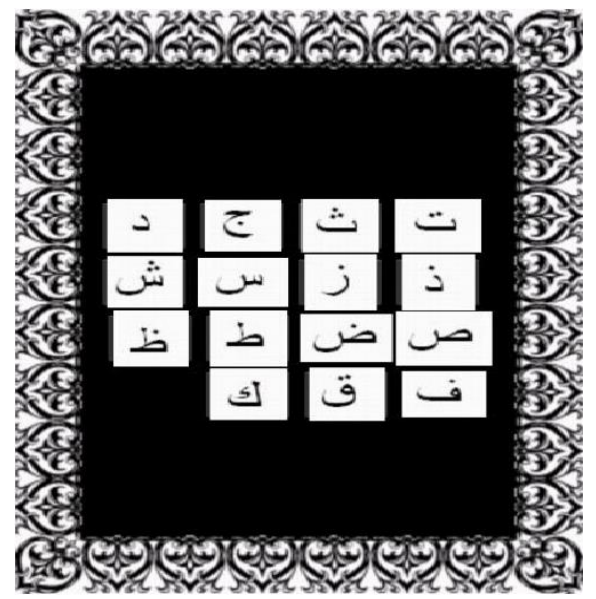

Gambar 3.8 ikhfa 


\section{Ikhfa}

Ikhfa menurut bahasa ialah samar atau tertutup sedankan menurut istilah ikhfa adalah mengucapkan huruf dengan sifat antara idzhar dengan idgham, tanpa tasydid dan menjaga ghunnah pada huruf yang di ikhfa'kan. Adapun huruf ikhfa seperti pada gambar 3.8

\section{Iqlab}

Iqlab menurut bahasa artinya mngganti, sedangkan menurut istilah iqlab mengganti bunyi bacaan nun mati atau tanwin menjadi mim. Adapun huruf iqlab seperti pada gambar 3.9

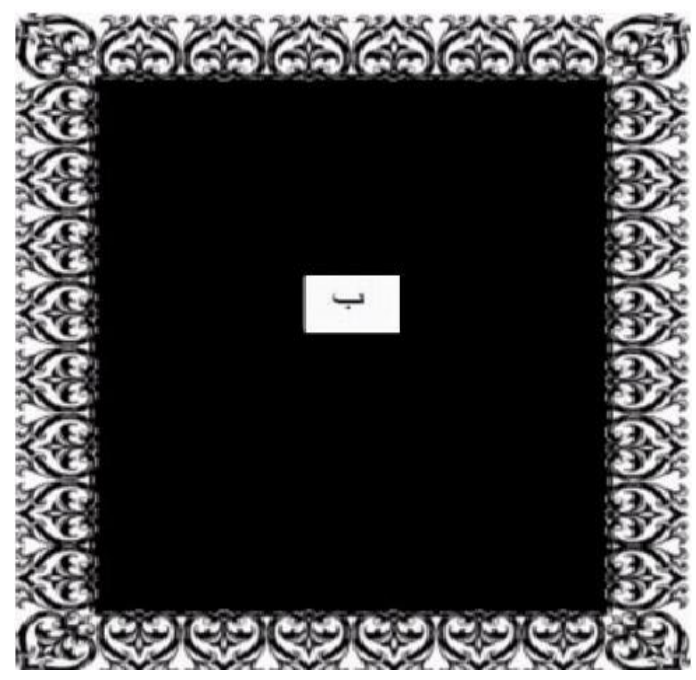

Gambar 3.9 iqlab

\section{Kuis}

Kuis adalah suatu pertanyaan atau game yang telah dibuat didalam aplikasi pembelajaran ini. Dimana kuis ini terdiri dari 10 soal yang di ambil dari materi yaitu huruf idzhar, idgham bighunnah, idgham bilaghunnah, ikhfa' dan iqlab. Adapun contoh kuis yang ada didalam aplikasi seperti pada gambar pada 3.10. 


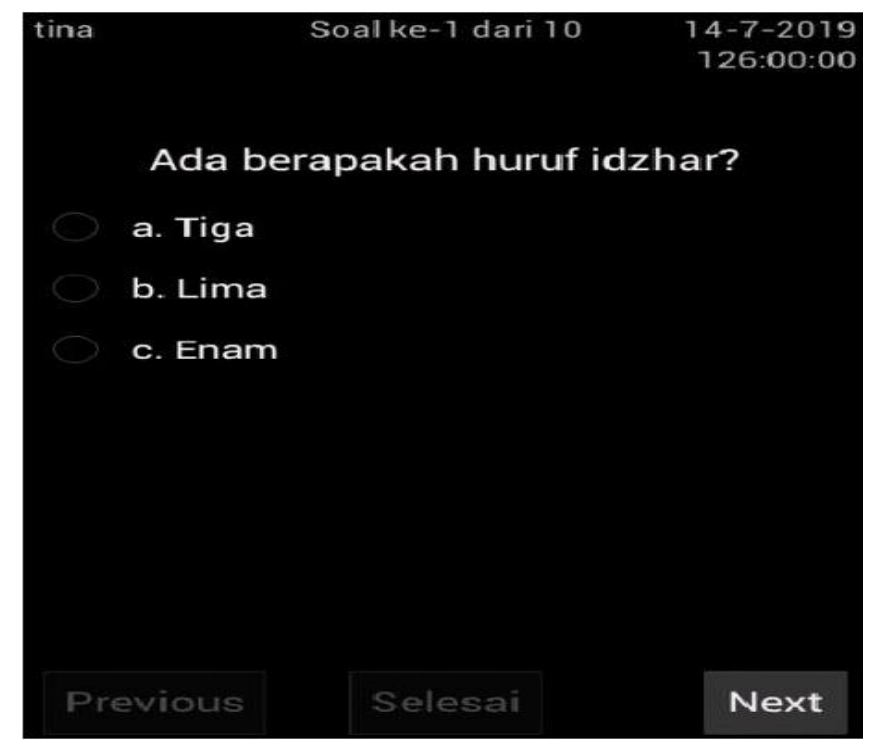

Gambar soal kuis 3.0

Dalam kuis tersebut pengguna dapat mengampilkasikan dengan menjawab soal-soal yang ada didalam kuis tersebut. Dimana dalam kuis ini ada 10 soal dan setiap soal memiliki skor 10. Apabila pengguna menjawab soal dengan benar maka mendapatkan nilai 100. Adapun gambar nilai yang telah dijawab dengan benar seperti pada gambar 3.11.

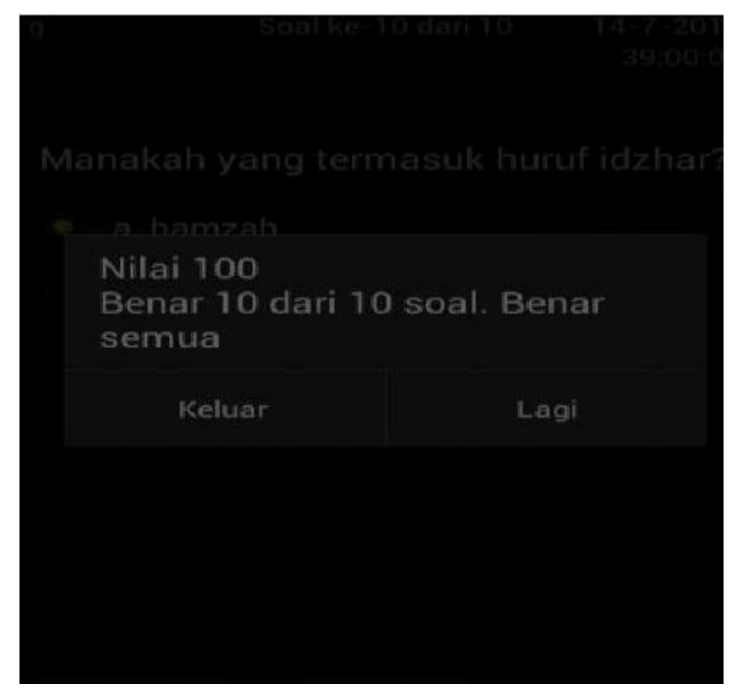

Gambar nilai kuis 3.11 


\section{Tampilan Huruf Hijaiyyah}

Pada menu huruf hijaiyyah akan menampilkan beberapa huruf yang terdiri dari 28 huruf hijaiyyah . Seperti pada gambar 3.12

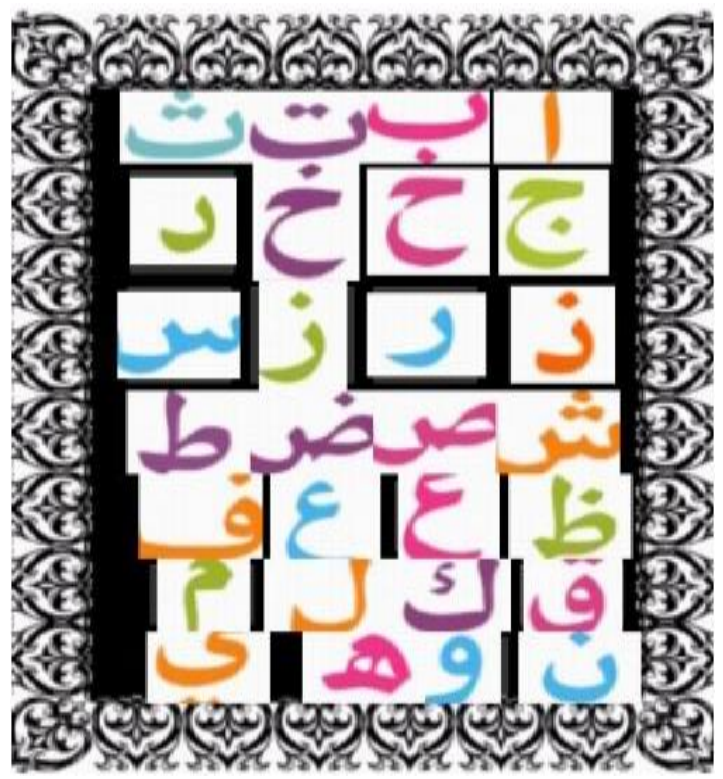

Gambar 3.12 menu materi huruf hijaiyyah 


\section{Foto-foto kegiatan}

Foto pada kegiatan pendampingan:
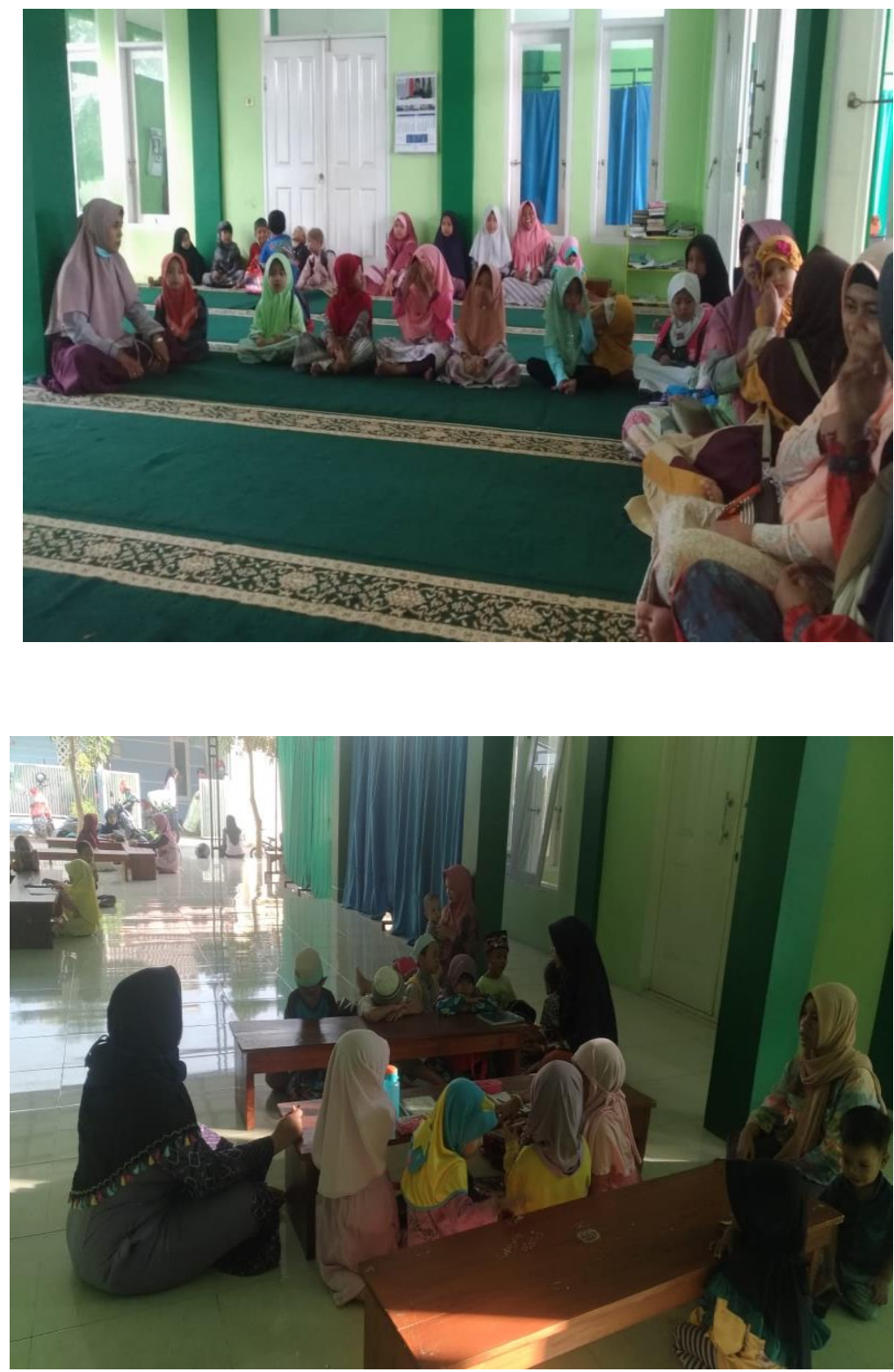

\section{Kesimpulan}

Hasil dari pendampingan dan pelatihan dalam penggunaan media pembelajaran ilmu tajwid terhadap ustazah dan murid-murid di TPQ Attarbiyah dapat disimpulkan sebagai berikut 
1. Media yang telah di bangun mudah digunakan berdasarkan uji coba yang telah dilakukan.

2. Murid dapat mempelajari hukum-hukum bacaan ilmu tajwid melalui media pembelajaran yang telah di bangun.

\section{Pengakuan}

Ucapan terimakasih kepada ustazah-ustazah yang telah berkenan menerima serta memberikan fasilitas dalam pelaksanaan Pengabdian kepada Masyarakat Pendampingan pelatihan dan pembelajaran tata cara membaca al-quran dengan ilmu tajwid di TPQ At-tarbuyah yang telah memberikan kepercayaan terhadap dosen serta teman-teman mahasiswa dalam pelaksanaan pengabdian kepada masyarakat, kegiatan ini memberikan wawasan lebih bagi mahasiswa selain pembelajaran yang diperoleh dari meja kampus. Tidak lupa pula kepada LP3M Universitas Nurul Jadid yang selalu memberikan dorongan serta bantuan agar terlaksananya pengabdian kepada masyarakat kolaborasi dosen dengan mahasiswa ini. Semoga kegiatan yang telah selesai ini memberikan dampat yang baik bagi pelaksana kegiatan, mahasiswa serta lembaga yang menerima kegiatan ini.

\section{Daftar Pustaka}

Abdurrohim. A. I. (2003). Ilmu tajwid lengkap.Buku Tajwid.25.

Achmad Roesyadi Mandasini . (2002) Aplikasi ilmu tajwid berbasis android.

Bonomo.M. (1973).Definisi Membaca menurut para ahli, 119

Bulaeng. (2016) Peningkatan kemampuan membaca al-qur'an dengan tartil melalui metode iqra pada siswa kelas $V$ di SD inpres tinggimae kecamatan somba opu kabupaten gowa, 1.

Shalahuddin. R. A. (2013). Rekayasa perangkat lunak terstruktur dan berorientasi objek. Bandung: Informatika.

Sopiah. E. M. (2010). Pendekatan praktis dalam penelitian. Metodologi penelitian: Yokyakarta: Andi.

Vitya, E. S. (2015). Pengembangan aplikasi pembelajaran iqra' dan tajwid berdasarkan metode asy-syafi'i menggunakan sistem multimedia. 
Jurnal Algoritma,

Gunadi. A. S.. Gani Hamdi \& Krisnawati. (2002). Membangun aplikasi berbasis android pembelajaran psikotes menggunakan app inventor, 38.

Humam. (2002). Aplikasi ilmu tajwid berbasis android, 3.

Isna Mildayanti. K. R. (2016).Pengembangan game edukasi tajwid al-qur'an berbasis android. Kumpulan Artikel Mahasiswa Pendidikan Teknik Informatika, 2.

Jogiyanto. Donny Indra Purnama Jati. (2001). Aplikasi pembelajaran dasar fotografi berbasis multimedia. Jurnal Tugas Akhir, 4.

Larman. Tri A.Kurniawan. (2005). Pemodelan use case (UML) evaluasi terhadap beberapa kesalahan dalam praktik, 79 .

Nurhidayah. H. M. (2010). Rancang bangun multimedia pembelajaran ilmu tajwid guna peningkatan pemahaman cara membaca al-qur'an. Jurnal Article Juita, 31. 